\title{
Article \\ Principal Component Analysis of Heavy Metals in Atmos- pheric Aerosols from Meycauayan, Bulacan, Philippines
}

\author{
Maria Cecilia Galvez 1,*, Edgar Vallar 1, Red Castilla 1, Paulito Mandia 1, Regine Branzuela 1, Ofelia Rempillo ${ }^{1}$, \\ Aileen Orbecido ${ }^{2}$, Arnel Beltran ${ }^{2}$, Nadine Ledesma ${ }^{3}$, Custer Deocaris ${ }^{4,5}$, Vernon Morris ${ }^{6}$, and \\ Lawrence Belo 2,5 ,*
}

1 Department of Physics, De La Salle University, Manila 0922 Philippines; edgar.vallar@dlsu.edu.ph (E.V); ofelia.rempillo@dlsu.edu.ph (O.R.); red_m_castilla@dlsu.edu.ph (R.C.); paulito_mandia@dlsu.edu.ph (P.M.); regine 1 branzuela@dlsu.edu.ph (R.B.)

2 Department of Chemical Engineering, De La Salle University, Manila 0922 Philippines; aileen.orbecido@dlsu.edu.ph (A.O.); arnel.beltran@dlsu.edu.ph (A.B.)

3 College of Agriculture, University of Rizal System, Tanay, Rizal, Philippines; nadineadellia.ledesma@urs.edu.ph (N.L.)

4 Philippine Nuclear Research Institute, Department of Science and Technology, Quezon City, Philippines; ccdeocaris@pnri.dost.gov.ph (C.D.)

5 BANToxics, Quezon City, Philippines;

6 School of Mathematical and Natural Sciences, New College for Interdisciplinary Arts and Sciences, PO Box 37100, MC 1251, Phoenix, Arizona, USA; Vernon.Morris@asu.edu (V.M.)

* Correspondence: maria.cecilia.galvez@dlsu.edu.ph (M.G.); lawrence.belo@dlsu.edu.ph (L.B.); Tel.: (+ 63 2) 85244611

\begin{abstract}
This paper focuses on the application of principal component analysis (PCA) to conduct a source apportionment of atmospheric aerosols from 8 sampling locations along the MarilaoMeycauayan-Obando River System (MMORS). Aerosols were collected on May 2016 during the same time that water samples were collected. Elemental analysis was conducted using a scanning electron microscope coupled with energy dispersive x-ray (SEM-EDX). Carbon (C), nitrogen (N), oxygen $(\mathrm{O})$, sodium $(\mathrm{Na})$, magnesium $(\mathrm{Mg})$, aluminum $(\mathrm{Al})$, silicon $(\mathrm{Si})$, sulfur $(\mathrm{S})$, chlorine $(\mathrm{Cl})$, potassium $(\mathrm{K})$, calcium $(\mathrm{Ca})$, titanium $(\mathrm{Ti})$, manganese $(\mathrm{Mn})$, iron $(\mathrm{Fe})$, copper $(\mathrm{Cu})$, zinc $(\mathrm{Zn})$, bromine $(\mathrm{Br})$, niobium $(\mathrm{Nb})$, barium $(\mathrm{Ba})$, mercury $(\mathrm{Hg})$, and lead $(\mathrm{Pb})$ concentrations were measured and used as inputs in Principal Component Analysis (PCA). The aerosol samples showed the presence of heavy metals $\mathrm{Pb}$ and $\mathrm{Hg}$, elements that were also detected in trace amounts in the water measurements. Concentrations of heavy metals $\mathrm{Fe}, \mathrm{Pb}, \mathrm{Hg}$ in the aerosols were attributed to industrial sources. However, it was determined that the primary source of aerosols in the area were traffic and crustal emissions ( $\mathrm{C}, \mathrm{N}, \mathrm{O}, \mathrm{Si}, \mathrm{Al}, \mathrm{Ca}$ ). Thus, control of traffic emissions would be more beneficial in reducing aerosol emissions in Meycauayan.
\end{abstract}

Keywords: Meycauayan; aerosols; source apportionment; principal component analysis; MMORS

\section{Introduction}

Meycauayan is an urban city located in the province of Bulacan, Philippines. As of 2010, amongst all the cities in the province of Bulacan, Meycauayan has the highest population density with a population of 199,154 and over a land area of 3,210 hectares [1]. Its major industries are fine jewelry making, leather products manufacturing and commercial establishments. Along with its industries, there are also several industrial parks located in the city as well as manufacturing companies [2].

Meycauayan, and its neighbouring towns Marilao and Obando, also contain the Marilao-Meycauayan-Obando River System (MMORS), which has been named as one of the top 30 dirtiest rivers in the world by the non-profit environmental group Blacksmith Institute [3,4]. The major causes of pollution in MMORS are effluents that contain heavy metals, organic wastes and other hazardous materials from industries [5]. The importance 
of MMORS as a pollution hotspot has led to studies on the pollution assessment of the river system [6]. Conversely, the increasing number of motor vehicles in Meycauayan should also be a concern. In 2007, the Meycauayan District Office of the Regional Land Transportation Office registered the greatest number of motor vehicles.

Atmospheric aerosols are a mixture of solid and liquid particles suspended in the air, which includes both organic and inorganic particles, and vary greatly in size, composition, and origin [7]. Human activities, especially in urban areas, have an enormous impact on the amounts of aerosols generated, as well as on the population's health. The main sources of aerosols come from industries such as steel and iron works, chemical manufacturing, oil depots and the automotive fleet [8].

There are only a few and limited studies conducted to characterize aerosols in Meycauayan, specifically in heavy metal pollution from major industries, and motor vehicles. A study on the contribution of different sources of aerosols in Meycauayan is needed as it is important in the future for providing solutions and action plans to decrease pollution. Information about the size, morphology and composition of aerosols in the atmosphere can provide clues about its source. One technique used is the scanning electron microscopy coupled with energy dispersive X-ray spectroscopy (SEM-EDX) [9]. In this paper, a rapid assessment of the possible sources of aerosols collected along the surrounding area of MMORS is presented. A statistical multivariate dimension reduction technique was implemented, and air mass isobaric backward trajectories using Hybrid Single-Particle Lagrangian Integrated Trajectory (HYSPLIT) Model [10] was carried out to analyze the sources and transport of aerosols in Meycauayan, Bulacan. This article is a part of a threepart study that investigated heavy metal pollution in water [11], soil [12], and air environments.

\section{Materials and Methods}

\subsection{Study Area}

Meycauayan city, Bulacan is about 19 kilometers north of Manila and about 22 kilometers south of Malolos city, the capital city of the province of Bulacan (between $14.738^{\circ}$ and $14.755^{\circ}$ north and between $120.943^{\circ}$ and $120.995^{\circ}$ east) [13]. It is bounded by the town of Marilao to the north, Valenzuela City to the south, Caloocan City to the east and the town of Obando to the west [2]. Major industries include fine jewelry making, leather products manufacturing and commercial establishments [2]. Steel rolling mills are also being operated in the city of Meycauayan and its neighboring municipality Plaridel, Bulacan [14]. Furthermore, the province of Bulacan is also considered the biggest producer of used lead acid battery (ULAB) [13]. The neighboring town, Marilao, houses a lead smelting plant owned by the largest lead battery recycler in the country as well as numerous unregulated ULAB plants [3,13].

Leather tanning industries are known emitters of Volatile Organic Compounds (VOCs) and Hazardous Air Pollutants (HAPs). Heavy metal air emissions from tannery operations are chromium $(\mathrm{Cr})$, chromium compounds, manganese $(\mathrm{Mn})$, and Manganese compounds [15]. Chromium compounds, identified as one of the HAPs emitted by tanning industries, mainly come from chromium salts, which are the most widely used tanning substance. When emitted into the atmosphere, $\mathrm{Cr}$ species are present in the form of particles and droplet aerosols [16]. Occupational exposure to hexavalent chromium compounds has been associated with increased risk of respiratory system cancers [17].

Meycauayan City is politically subdivided into twenty-six (26) barangays. Sampling sites were chosen from eight different barangays in Meycauayan city. The eight barangays are as follows: (AQS1) Barangay Caingin, (AQS2) Barangay Banga, (AQS3) Barangay Calvario, (AQS4) Barangay Camalig, (AQS5) Barangay Langka, (AQS6) Barangay Perez, (AQS7) Barangay Iba and (AQS8) Barangay Malhacan. The barangays were selected to represent the different land classifications according to use whether agricultural, industrial, residential, or just open space. The eight (8) air quality sampling (AQS) locations shown in Figure 1 and described in Table 1. 


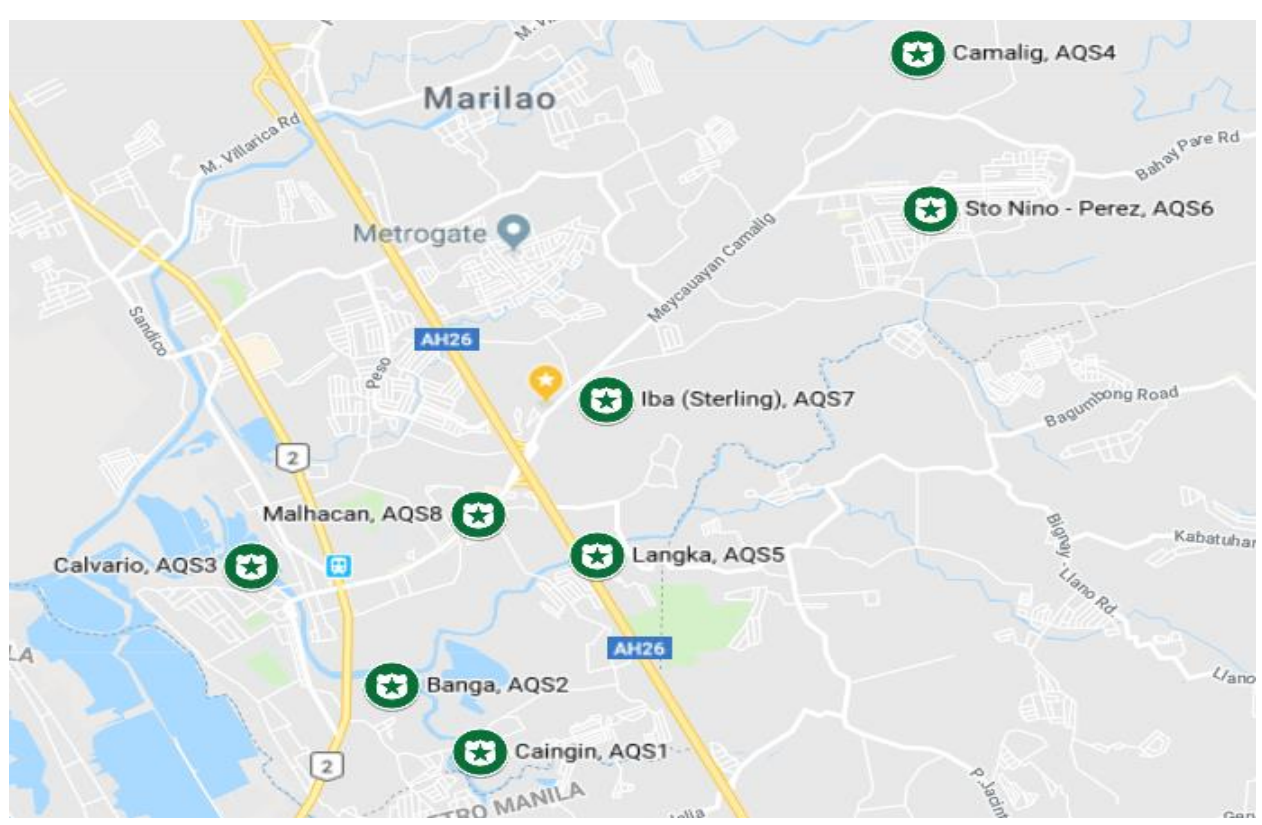

Figure 1. Locations of aerosol sampling (AQS) stations (Google Maps)

Table 1. Aerosol sampling (AQS) point locations in Meycauayan City.

\begin{tabular}{cccc}
$\begin{array}{c}\text { Sampling } \\
\text { point }\end{array}$ & $\begin{array}{c}\text { Location } \\
\text { address }\end{array}$ & Coordinates & $\begin{array}{c}\text { Typical } \\
\text { Land Use 1 }\end{array}$ \\
\hline AQS1 & Caingin & $\begin{array}{c}\mathrm{N}-14.725092^{\circ} \\
\mathrm{E}-120.96978^{\circ}\end{array}$ & $\begin{array}{c}\text { Reclaimed dumpsite } \\
\text { / Residential }\end{array}$ \\
\hline AQS2 & Banga & $\mathrm{N}-14.73000^{\circ}$ & $\begin{array}{c}\text { Residential / } \\
\text { Commercial }\end{array}$ \\
\hline AQS3 & Calvario $-120.96417^{\circ}$ & $\mathrm{N}-14.73866^{\circ}$ & $\begin{array}{l}\text { Residential / } \\
\text { Commercial }\end{array}$ \\
\hline AQS4 & Camalig & $\mathrm{N}-14.77612^{\circ}$ & Agricultural \\
\hline AQS5 & Langka & $\mathrm{N}-14.73944^{\circ}$ & $\begin{array}{c}\text { Residential / } \\
\text { Agricultural }\end{array}$ \\
\hline AQS6 & Sto. Niño - & $\mathrm{N}-14.76472^{\circ}$ & $\begin{array}{l}\text { Residential / } \\
\text { Commercial }\end{array}$ \\
\hline AQS7 & Perez & $\mathrm{E}-120.99833^{\circ}$ & Industrial \\
\hline \multirow{2}{*}{ AQS8 } & Iba & $\mathrm{N}-14.75083^{\circ}$ & Residential/ \\
& Malhacan & $\mathrm{N}-14.74245^{\circ}$ & Commercial \\
\hline
\end{tabular}

${ }^{1}$ Typical land use sourced from Manalo (2015) [18]

The location of AQS1 (Caingin) is a former dumpsite but people continue to throw garbage in the area. There were also people living around this dump site. AQS2 (Banga) is an open space area wherein trucks used for construction are being kept. There are no residences within this area. AQS3 (Calvario) has a public market and an open space wherein some people throw garbage and turn it into a dump site. There are about three to four families living in this area who are caretakers of the land. Flooding is also evident in this area even if the sampling was done during the summer season, which has minimal or no rain at all. AQS4 (Camalig) is identified as agricultural land because there are still plantation and there are no industrial buildings. In AQS5 (Langka), there are industries 
situated along the riverbanks and a residential area as well. AQS6 (Perez) is a purely residential area, the sampling here was done inside a subdivision. AQS7 (Iba) is a purely industrial land where there are factories and warehouses around the sampling site. Lastly, the sampling site AQS8 (Malhacan) is along the roadside. The mentioned barangays are situated along the riverbanks except for barangay Camalig, Iba and Malhacan.

\subsection{Aerosol Sampling and Analysis}

Collection was carried out during the summer season (May 2016). On the first day, samples were taken from barangays Caingin, Banga, and Calvario at around $1500 \mathrm{H}$ to $1800 \mathrm{H}$. On the second day, samples were taken from the rest of the barangays at around $0800 \mathrm{H}$ to $1200 \mathrm{H}$. An air pump was used to suction surrounding air with a sampling flow rate of about $83.5 \mathrm{SCFH}$ (or $2.35 \mathrm{~m}^{3} / \mathrm{h}$ ) [19,20]. Aerosols were deposited on glass-fiber filters at fifteen minutes per location. The filters were changed every barangay and labeled according to sampling site.

During the analysis, a quadrant is taken from each filter and coated with gold using a JEOL JFC-1200 Fine Coater. The prepared filter is then studied using the JEOL JSM-5310 Scanning Electron Microscope (SEM) with an accelerating voltage of $15-20 \mathrm{kV}$ and spot size of 7. For elemental analysis, the attached Energy Dispersion X-ray (EDX) feature of the SEM was used with a spot size of 12. Randomly selected particles from each filter were studied for morphology and elemental composition. The imaging software used was SemAfore version 5.2.1.

\section{Results and Discussions}

\subsection{Air Mass Backward Trajectory (AMBT)}

To analyze the sources and transport of aerosol particles at the research locale, the air mass backward trajectories were calculated for the sampling period. The researchers used isobaric backward trajectories that were calculated and plotted using Hybrid Single-Particle Lagrangian Integrated Trajectory (HYSPLIT) Model and the meteorological data of National Oceanic and Atmospheric Administration's (NOAA) Air Resources Laboratory [10].

Three-day backward trajectories, during sampling periods, were calculated for 500 $\mathrm{m}$ above ground level (AGL) ending at 06:00 UTC. The dominance of long trajectories, evident on the AMBTs in the map (Figure 2), shows that air masses generally came from the Pacific (East of the Philippines) and headed due West towards the sampling location. This might indicate a long-range transport of particles specifically those of maritime in nature. However, the ABMTs versus altitude plot shows that air masses at $500 \mathrm{~m}$ are influenced by local processes. This is supported by the ABMTs generated at every six hours for $36 \mathrm{~h}$ which all curve upward from the surface to $500 \mathrm{~m}$ AGL.

This only means that, for the samplings performed in this study, all elements with high factor loadings can be attributed to local urban processes and cannot be attributed to transboundary phenomena. This reflects the transport of aerosol particles with mostly anthropogenic origin. 
NOAA HYSPLIT MODEL

Backward trajectories ending at 0700 UTC 11 May 16 GDAS Meteorological Data

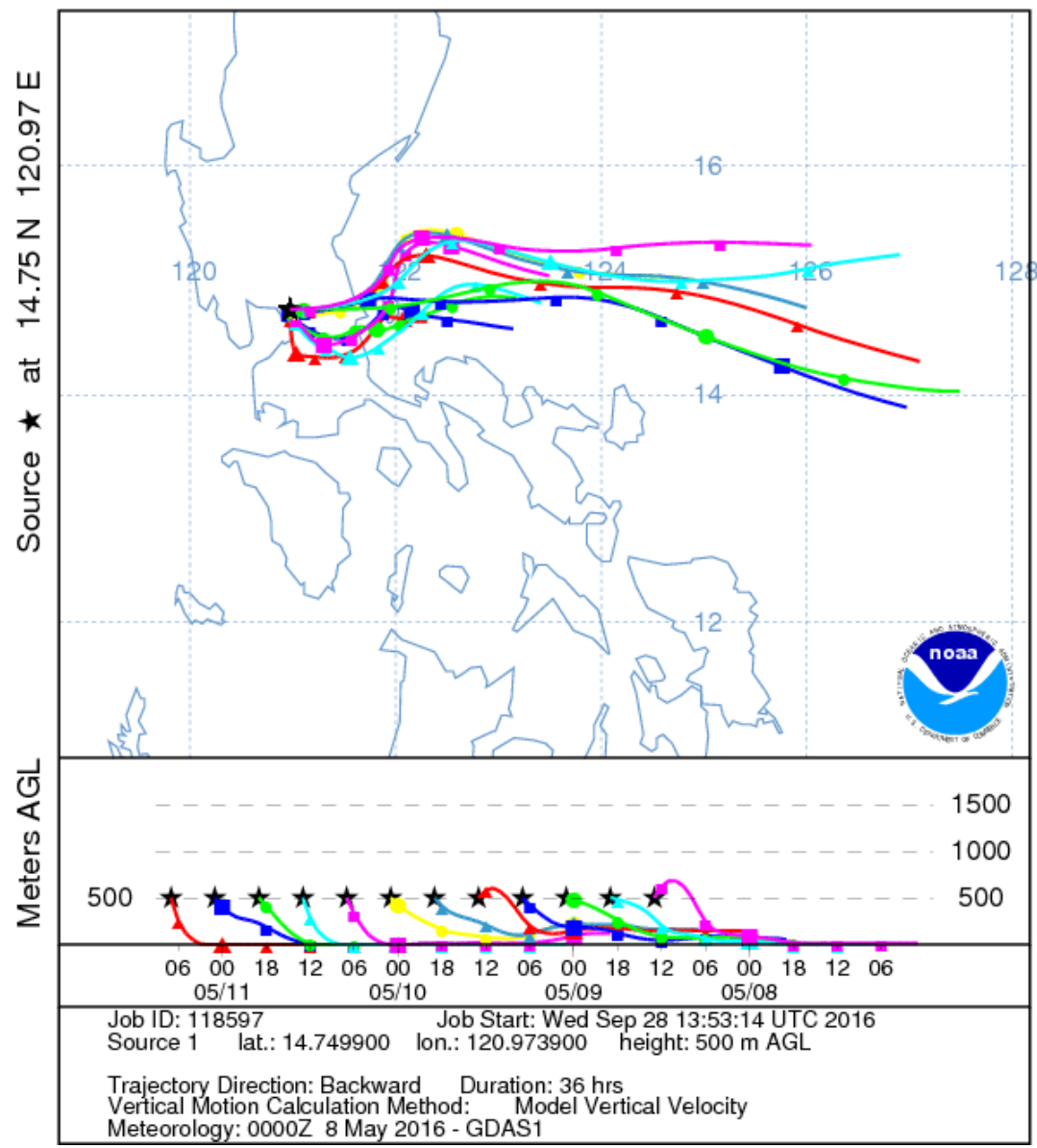

Figure 2. Three-day air mass back trajectory plot using the Hybrid Single-Particle Lagrangian-Integrated Trajectory (HYSPLIT) Model for 10th \& 11th of May 2016 aerosol sampling at Meycauayan, Bulacan. A new trajectory is calculated every six hours with each having a $36-\mathrm{h}$ integrating time at 500 meters above ground level.

\subsection{Aerosol Characterization}

A total of eighty (80) particles were analyzed by scanning electron microscopy (SEM) and energy dispersive x-ray (EDX) analysis for the rapid-assessment of Meycauayan, Bulacan's surface atmosphere. Table 2 shows the summary statistics of the concentration of each element from the eight selected sites. The first column specifies the element, the second column shows the mean elemental concentration in mass per mass percentage $(\mathrm{m} / \mathrm{m}) \%$, the third column lists the respective standard deviations, the fourth column presents the coefficient of variation which is the ratio between the standard deviation and the mean (this facilitates easier inter-comparison of the spread of data among each variable), and the last column shows the number of cases used in the analysis.

The elemental concentrations of both $\mathrm{O}$ and $\mathrm{C}$ prove to dominate the mean elemental concentration of all samples ( $\sim 50 \%)$. This suggests the dominant presence of several oxides and carbonaceous particles. The remaining $~ 50 \%$ is divided across the 19 elements on the average, with $\mathrm{Si}$ and $\mathrm{N}$ constituting about half of this remainder. This, on the other hand, somehow implies the existence of biogenic and geogenic origins of the particles analyzed. Further, what is left might be attributed to sources of anthropogenic nature.

Table 2. Descriptive statistics of the elemental concentration $(\mathrm{m} / \mathrm{m}) \%$ of aerosol samples from selected sites in Meycauayan, Bulacan. 


\begin{tabular}{lrrrr}
\hline Elements & Mean & Std. Dev. & Coef. Var. & $\mathbf{N}$ \\
\hline $\mathrm{O}$ & 32.6536 & 19.4852 & 0.5967 & 80 \\
\hline $\mathrm{C}$ & 20.3635 & 20.1236 & 0.9882 & 80 \\
\hline $\mathrm{Si}$ & 15.7427 & 15.018 & 0.954 & 80 \\
\hline $\mathrm{N}$ & 8.8394 & 12.4085 & 1.4038 & 80 \\
\hline $\mathrm{Na}$ & 4.0574 & 4.3291 & 1.067 & 80 \\
\hline $\mathrm{Ba}$ & 3.2513 & 4.9786 & 1.5312 & 80 \\
\hline $\mathrm{Ca}$ & 3.0306 & 4.656 & 1.5363 & 80 \\
\hline $\mathrm{Zn}$ & 2.1065 & 3.0699 & 1.4573 & 80 \\
\hline $\mathrm{Hg}$ & 2.0446 & 2.3458 & 1.1473 & 80 \\
\hline $\mathrm{Al}$ & 1.9961 & 1.5283 & 0.7657 & 80 \\
\hline $\mathrm{Nb}$ & 1.9478 & 3.6362 & 1.8668 & 80 \\
\hline $\mathrm{K}$ & 1.6873 & 1.7847 & 1.0577 & 80 \\
\hline $\mathrm{Fe}$ & 1.1221 & 4.5642 & 4.0676 & 80 \\
\hline $\mathrm{Pb}$ & 0.45 & 1.9363 & 4.3028 & 80 \\
\hline $\mathrm{Mg}$ & 0.3915 & 0.7984 & 2.0392 & 80 \\
\hline $\mathrm{S}$ & 0.1514 & 0.6409 & 4.2332 & 80 \\
\hline $\mathrm{Cl}$ & 0.0873 & 0.3812 & 4.3666 & 80 \\
\hline $\mathrm{Br}$ & 0.0301 & 0.2695 & 8.9518 & 80 \\
\hline $\mathrm{Ti}$ & 0.0202 & 0.1572 & 7.7822 & 80 \\
\hline $\mathrm{Cu}$ & 0.019 & 0.0877 & 4.6179 & 80 \\
\hline $\mathrm{Mn}$ & 0.0083 & 0.0738 & 8.8904 & 80 \\
\hline & & & &
\end{tabular}

\subsection{Source Identification by Principal Component Analysis (PCA)}

To source apportion the sampled aerosols, a statistical multivariate dimension reduction technique was implemented. As performed in previous studies [21-25], factor analysis with PCA extraction method was applied to the elemental concentration matrix which was then followed by an orthogonal rotation via varimax algorithm of the scaled principal components (PC). This generated associated groups of correlated elements that correspond to the main chemical compounds that are spawned by diverse emission sources.

The PCA method to source apportionment assumes that the total concentration of each particle is the summation of contributions from each of a smaller number of underlying pollution source components. A correlation matrix of the input variables (elemental concentrations) forms the basis in the derivation of source-related components and their associated profiles by PCA. Twenty-one input variables were considered for the PCA of the Meycauayan aerosol sample elemental concentration data: $\mathrm{C}, \mathrm{N}, \mathrm{O}, \mathrm{Na}, \mathrm{Mg}, \mathrm{Al}, \mathrm{Si}, \mathrm{S}$, $\mathrm{Cl}, \mathrm{K}, \mathrm{Ca}, \mathrm{Ti}, \mathrm{Mn}, \mathrm{Fe}, \mathrm{Cu}, \mathrm{Zn}, \mathrm{Br}, \mathrm{Nb}, \mathrm{Ba}, \mathrm{Hg}$, and Pb.

In performing PCA for source apportionment, acquiring a satisfactorily high fraction of the total variance explained by the selected principal components was first put in place. To achieve this, the total eigenvalues of and the percent of variance explained by each component must be calculated. Components with eigenvalues greater than 1.0 were retained for these can reasonably correspond to major air pollution sources. Once the number of principal components was chosen, the minimization of cross-loadings between components to maximize intra-component association among variables was accomplished by applying an orthogonal rotation algorithm - varimax.

In the identification process of the particle origin, several groups of elements were associated with one or various emission sources. These associations were based from existing literature [25-27] on the possible elemental composition and morphology of a specific type of particle and its corresponding source. Element groups related to a specific type of particle origin could be used as tracers of the main particles emitted by the pollution sources [25].

A seven-component solution using varimax rotation was determined to be the optimal solution based on the examination of the PC eigenvalues, the total variance explained 
by each PC, and the source-related interpretability of the components. For this study, a value of $75.114 \%$ was obtained as the cumulative percent of the total variance explained by retaining seven principal components. Figure 3 illustrates the scree plot depicting the eigenvalues of the seven principal components retained. The threshold marker at eigenvalue equals 1.0 emphasizes that the retained PCs have individual accumulated eigenvalues greater than 1.0. The corresponding eigenvalues of each PC can be seen at the bottom part of Table 3, together with the percent of variance explained by each PC.

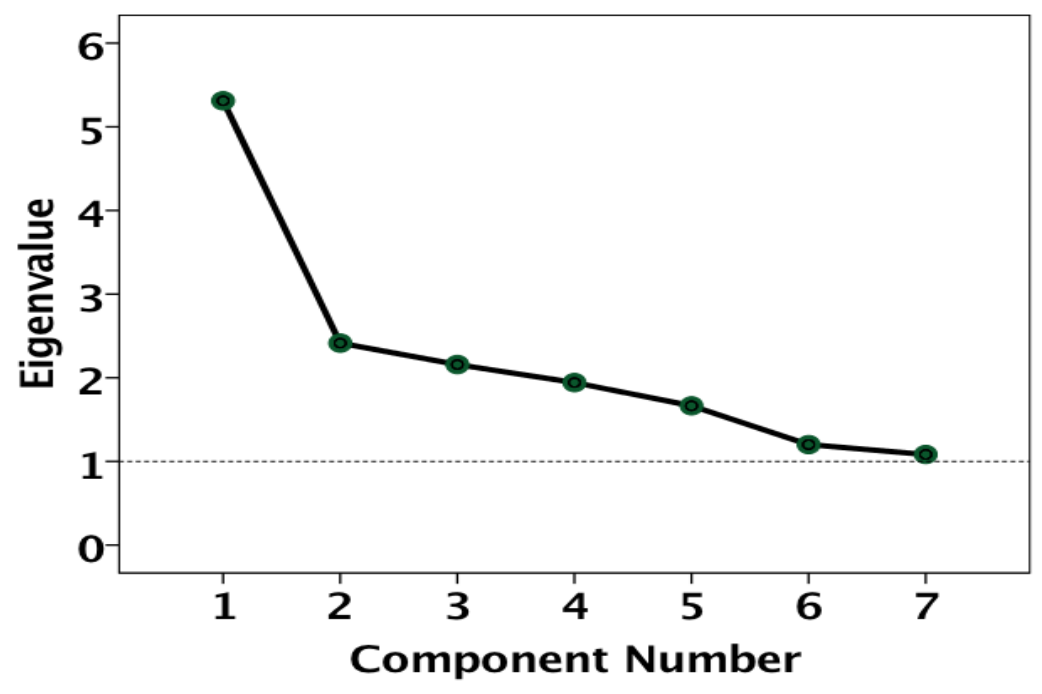

Figure 3. Scree plot of the principal components formed from reducing the dimension of the multivariate elemental concentration of aerosol samples from selected sites in Meycauayan, Bulacan.

Table 3 also layouts the matrix of component loadings for each of the PC retained. These component loadings pertain to the correlation between a principal component and the variable inputs for PCA, which in this study are the elemental concentrations of the aerosol samples. Highlighted in green are the elements with significantly strong and positive correlation with PCs, while in red are those with significantly strong and negative correlation with PCs, these aid in the interpretation of the retained components. Physically identifying the principal components is performed by comparing the elements with highest loadings with each PC, with the elements discharged in high concentrations by known source types according to previous documentation. 
Table 3. Rotated eigenvalue sums, total variance explained, and loadings of the principal components from the multivariate elemental concentration of aerosol samples from selected sites in Meycauayan, Bulacan.

\begin{tabular}{c|ccccccc}
\hline \multirow{2}{*}{ Elements } & \multicolumn{7}{|c}{ Principal Component } \\
& 1 & 2 & 3 & 4 & 5 & 6 & 7 \\
\hline $\mathrm{C}$ & -0.377 & -0.044 & -0.034 & -0.066 & $\underline{-0.861}$ & -0.023 & -0.024 \\
$\mathrm{~N}$ & -0.402 & -0.130 & -0.120 & $\underline{-0.752}$ & 0.131 & 0.015 & 0.053 \\
$\mathrm{O}$ & $\underline{-0.632}$ & -0.060 & -0.111 & 0.225 & $\underline{0.652}$ & -0.080 & 0.013 \\
$\mathrm{Na}$ & $\underline{0.725}$ & -0.048 & -0.179 & 0.286 & 0.074 & 0.359 & 0.059 \\
$\mathrm{Mg}$ & 0.016 & -0.030 & $\underline{0.731}$ & -0.196 & 0.293 & -0.006 & 0.168 \\
$\mathrm{Al}$ & $\underline{0.627}$ & -0.102 & 0.279 & 0.228 & 0.077 & -0.278 & 0.394 \\
$\mathrm{Si}$ & $\underline{0.916}$ & 0.021 & 0.009 & 0.218 & 0.037 & -0.188 & 0.031 \\
$\mathrm{~S}$ & -0.065 & -0.075 & 0.114 & 0.279 & 0.324 & 0.134 & $\underline{-0.627}$ \\
$\mathrm{Cl}$ & -0.021 & $\underline{0.630}$ & -0.064 & -0.018 & -0.031 & -0.134 & 0.025 \\
$\mathrm{~K}$ & $\underline{0.909}$ & -0.066 & -0.038 & 0.059 & 0.030 & 0.054 & -0.032 \\
$\mathrm{Ca}$ & -0.060 & -0.022 & $\underline{0.871}$ & -0.034 & -0.042 & 0.082 & -0.123 \\
$\mathrm{Ti}$ & -0.047 & -0.022 & $\underline{0.652}$ & 0.209 & -0.399 & -0.077 & 0.028 \\
$\mathrm{Mn}$ & -0.083 & -0.028 & 0.076 & 0.193 & 0.188 & 0.060 & $\underline{0.732}$ \\
$\mathrm{Fe}$ & -0.067 & $\underline{0.937}$ & 0.048 & -0.019 & 0.003 & 0.040 & -0.005 \\
$\mathrm{Cu}$ & $\underline{0.612}$ & -0.026 & -0.056 & -0.042 & -0.036 & 0.163 & 0.078 \\
$\mathrm{Zn}$ & $\underline{0.931}$ & 0.042 & 0.033 & -0.125 & 0.064 & -0.034 & -0.044 \\
$\mathrm{Br}$ & -0.036 & $\underline{0.918}$ & -0.026 & 0.026 & 0.039 & 0.102 & -0.022 \\
$\mathrm{Nb}$ & -0.181 & -0.118 & -0.171 & $\underline{0.791}$ & 0.303 & -0.144 & 0.101 \\
$\mathrm{Ba}$ & $\underline{0.756}$ & -0.098 & -0.048 & -0.028 & 0.084 & 0.015 & -0.141 \\
$\mathrm{Hg}$ & -0.134 & 0.076 & 0.209 & -0.416 & 0.011 & $\underline{0.707}$ & -0.243 \\
$\mathrm{~Pb}$ & 0.184 & -0.071 & -0.066 & 0.044 & 0.001 & $\underline{0.882}$ & 0.074 \\
\hline Eigenvalue & 5.208 & 2.201 & 1.968 & 1.822 & 1.691 & 1.642 & 1.242 \\
Variance \% & 24.799 & 10.480 & 9.371 & 8.676 & 8.054 & 7.821 & 5.914 \\
Cumulative \% & 24.799 & 35.278 & 44.649 & 53.325 & 61.379 & 69.200 & 75.114 \\
\hline
\end{tabular}

Note: texts in green and red show high positive and negative correlations, respectively.

Nevertheless, similar to all other source apportionment analyses, PCA poses a potential limitation where other sources of the significant trace elements appearing from a source category not determined in the analysis can be statistically "sensed" and assigned to the most characteristically similar identified source component; possibly overstressing the source-specific contribution estimates [23]. The seven-component PCA solution were physically identified to be the following:

- Component 1: Traffic \& Crustal Material ( 25\%) - The principal component with the highest percent of variance explained corresponds to that of Crustal Materials and traces of traffic-related elements due to fuel combustion ( $25 \%)$. High component loadings by $\mathrm{Na}, \mathrm{Al}, \mathrm{Si}, \mathrm{K}$, and $\mathrm{O}$ indicate that there is a dominant presence of particles with crustal or geogenic origin. This may include aluminosilicates in the form of fly ash (Al-Si-O), sodium-feldspar (Na-Al-Si-O), and potassium feldspar (KAl-Si-O). Aside from these, it is noticeable in Figure 4 Comp.1 that there are also high component loadings due to some categorically toxic ambient air elements $-\mathrm{Cu}, \mathrm{Zn}$, and $\mathrm{Ba}$. These trace elements are products of incomplete combustion of vehicular fuels; 
- Component 2: Industrial Emission 1 (Iron and Steel Manufacturing) ( 10\%) - The second principal component that takes the second highest percent of variance explained ( $10 \%)$ may be attributed to Industrial Emissions due to iron and steel manufacturing;

- Component 3: Ca-Rich Resuspension ( 9\%) - Particles with high Ca content fall into this principal component proving responsible for $\sim 9 \%$ of the total variance explained. The presence of these particles indicates the dominance of resuspended crustal material from roads, either paved or unpaved, and from construction activities;

- Component 4: Instrumental Bias ( 9 \%) - The fourth principal component brings out the instrumentation-based limitation in this study. High loadings by $\mathrm{Nb}$ on this component can be attributed to sample preparation prior to subjecting the samples to the EDX chamber, in which samples are gold coated. The software misidentifies some gold peaks as niobium's;

- $\quad$ Component 5: Carbonaceous Fractions ( 8 \%) - The carbonaceous materials account for the $\sim 8 \%$ of total variance explained in this study having strong loadings on both $\mathrm{C}$ and $\mathrm{O}$. Determining whether this carbonaceous material is elemental or organic could not be done in this current study. However, looking at the correlation between carbon and oxygen, this indicates that at high values of $\mathrm{C}, \mathrm{O}$ goes at its minimum. High carbon elemental concentration and low oxygen elemental concentration indicates dominant presence of soot particles;

- $\quad$ Component 6: Industrial Emission 2 (Gold Smelting) ( 8 \%) - A second industrial source that is responsible for $\sim 8 \%$ of the total variance explained has been identified in this study. This may be attributed to the manufacturing and processing of gold products for jewelry enterprises. High loadings on mercury indicate the use of $\mathrm{Hg}$ rich materials in high temperature processes for separation of impurities from gold particles. High $\mathrm{Pb}$-loadings can also be attributed to high temperature processes;

- $\quad$ Component 7: Traffic Exhaust ( 6\%) - The last principal component that is heavily loaded by $\mathrm{S}$ and $\mathrm{Mn}$ and which accounts for $\sim 6 \%$ of the total variance explained, can be associated with vehicular exhausts.

Plotting the values for the two major components (Figure 5), exhibits the groupings of the different elemental components. $\mathrm{Fe}, \mathrm{Br}$, and $\mathrm{Cl}$ grouped together correspond to iron and steel manufacturing emissions. Although $\mathrm{Br}$ and $\mathrm{Cl}$ can come from natural sources such as sea salt, this source is disregarded due to the lack of relationship with $\mathrm{Na}$. It is thus concluded that the $\mathrm{Br}$ and $\mathrm{Cl}$ are used in steel sheet production. $\mathrm{Cu}, \mathrm{Al}, \mathrm{Na}, \mathrm{Ba}, \mathrm{K}, \mathrm{Si}$, $\mathrm{Zn}$ are group together for high values of component 1 which relate to crustal and traffic sources. Crustal components could be released into the atmosphere through the resuspension of particles from wind or mechanical disturbances such as when vehicles passing through the roads leading to road side dust emissions. C, N, O, S group together form sources of aerosol formation. Carbon most likely comes from soot emissions, while the nitrogen and sulfur along with oxygen can be related to the $\mathrm{O}_{3}, \mathrm{NO}_{x}$ and $\mathrm{SO}_{2}$ emissions and their oxidation to form nitrates and sulfates. Major sources of soot, $\mathrm{O}_{3}, \mathrm{NO}_{x}$, and $\mathrm{SO}_{2}$ in urban cities are vehicular emissions. 

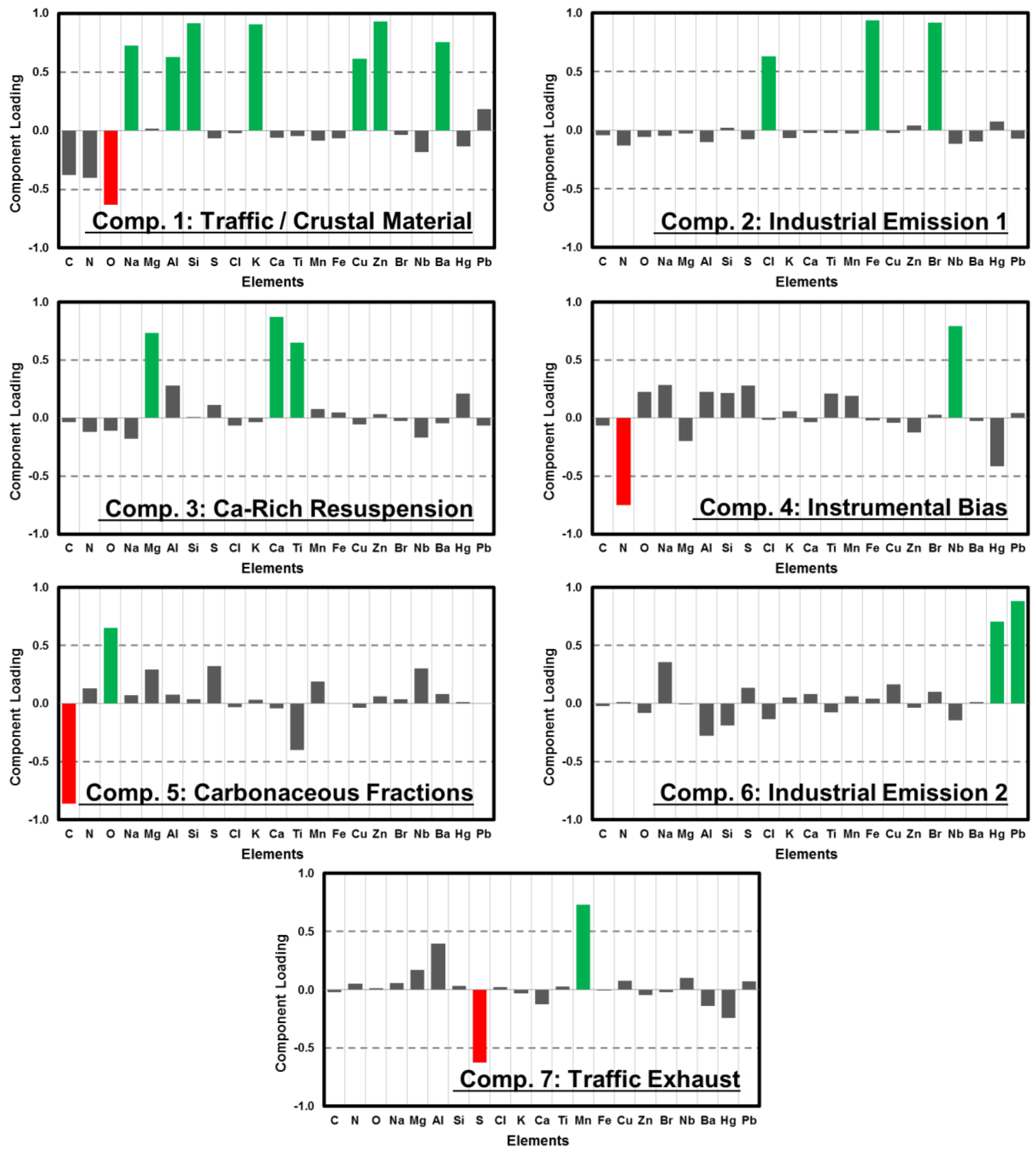

Figure 4. Bar plots of component loading per input variable (elements) for the seven retained principal components. Green bars indicate a significantly strong positive loading of a variable with a component $(>0.5)$; red bars indicate a significantly strong negative loading (<-0.5); grey bars indicate weak loading. 


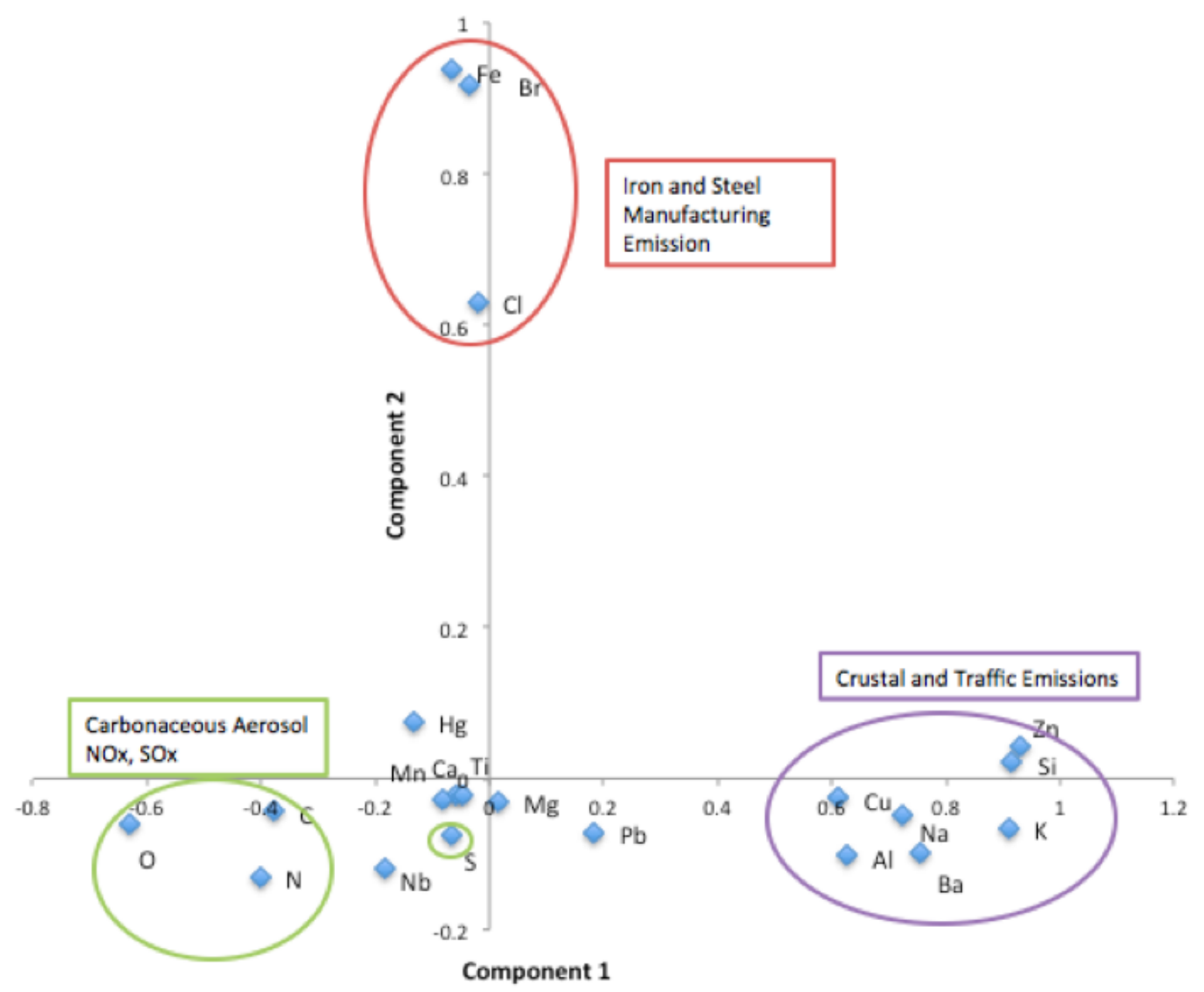

Figure 5. Component 2 vs Component 1

\section{Conclusions}

Analysis of the elemental composition of aerosols collected in Meycauayan city during the summer period of 2016 were conducted in this study. Results showed that the primary source of aerosols correspond to traffic emissions and crustal sources. Carbon from carbonaceous aerosols, nitrogen and oxygen form the major component of the aerosols. This points to $\mathrm{O}_{3}$ and $\mathrm{NO}_{x}$ emissions, which are precursors to aerosol formation. Sulfur which falls under the same component as manganese, can be attributed to vehicle exhaust emissions. $\mathrm{SO}_{2}$ is a product of fossil fuel combustion and forms sulfate in aerosol formation. $\mathrm{Cu}, \mathrm{Al}, \mathrm{Na}, \mathrm{Ba}, \mathrm{K}, \mathrm{Si}, \mathrm{Zn}$ are related to crustal sources with some elements coming from incomplete combustion of fuel. Crustal aerosols may be produced by resuspension of dust particles when vehicles pass over the roads. Thus, it is recommended that aerosol reduction can be achieved by regulating traffic emissions in the area.

Detection of heavy metals $\mathrm{Pb}, \mathrm{Hg}$ and Fe indicate that some of the aerosols come from industrial sources, namely jewelry making/gold smelting and steel production. $\mathrm{Pb}$ and $\mathrm{Hg}$ were also detected in water quality measurements consistent with their presence in the atmosphere. Cr was detected in the water samples but not in the atmospheric samples. Atmospheric concentrations of $\mathrm{Pb}, \mathrm{Hg}$ and Fe cannot be calculated from the SEM-EDX measurements. Thus, it cannot be determined if the atmospheric concentrations of these heavy metals are within acceptable limits. It is therefore recommended that a follow-up study be conducted to determine the atmospheric concentrations, using more quantitative methods such as atomic absorption spectroscopy (AAS), inductively coupled plasma mass spectrometry (ICP-MS), or energy dispersive $\mathrm{x}$-ray fluorescence (ED-XRF) spectroscopy. 


\begin{abstract}
Author Contributions: Conceptualization, M.G, E.V., L.B., A.O., N.L.; A.B. and C.D.; methodology, M.G., E.V., R.C., R.B., P.M. and O.R.; software, M.G., E.V., O.R. and V.M.; validation, M.G., E.V., R.C., R.B., P.M. and O.R.; formal analysis, R.C., R.B., P.M., O.R. and V.M.; investigation, M.G., E.V., R.C., R.B., P.M. and L.B.; resources, M.G., E.V., O.R. and V.M.; data curation, M.G., E.V., R.C., R.B., P.M. and O.R.; writing- original draft preparation, M.G., E.V., R.C., R.B., P.M., L.B. and O.R.; writing-review and editing, M.G., E.V., A.O., A.B., N.L., O.R., C.D. and L.B.; supervision, M.G., E.V., A.B., A.O., L.B. and C.D..; project administration, L.B. and C.D.; funding acquisition, C.D. All authors have read and agreed to the published version of the manuscript.
\end{abstract}

Funding: This research received no external funding.

Institutional Review Board Statement: Not applicable.

Informed Consent Statement: Not applicable.

Data Availability Statement: Not applicable.

Acknowledgments: The authors acknowledge the logistical and financial support for this project provided by the Grand Kawayan Foundation, Inc., thru its president Mr. Samuel Mora.

Conflicts of Interest: The authors declare no conflict of interest.

\title{
References
}

1. PSA Philippine Standard Geographic Code; Philippines, 2017;

2. Provincial Government of Bulacan Available online: http://www.bulacan.gov.ph/government/pcedo.php.

3. Blacksmith_Institute Water Stewardship: Protecting the Marilao, Meycauayan and Obando River System Available online: http://www.blacksmithinstitute.org/heavy-metal-pollution-in-the-mariloa-river.html.

4. GMA_News_Online Marilao, Meycauayan Listed among World's “Dirtiest" Available online: http://www.gmanetwork.com/news/news/regions/61154/marilao-meycauayan-listed-among-world-s-dirtiest/story/.

5. Mendoza, M.D. Clean the Marilao, Meycauayan and Obando [Bulacan, Philippines] River System Project [2006].; 2008.

6. David, C.P. Pollution Load Assessment in the Marilao - Meycauayan - Obando (MMO) River System WQMA.; Philippines, 2009.

7. WHO Health Aspects of Air Pollution with Particulate Matter, Ozone and Nitrogen Dioxide; World Health Organization: Bonn, Germany, 2003;

8. Landulfo, E.; Papayannis, A.; Artaxo, P.; Castanho, A.D.A.; de Freitas, A.Z.; Souza, R.F.; Junior, N.D.V.; Jorge, M.P.M.P.; Sanchez-Ccoyllo, O.R.; Moreira, D.S. Synergetic Measurements of Aerosols over Sao Paulo, Brazil Using LIDAR, Sunphotometer and Satellite Data during the Dry Season. Atmos. Chem. Phys. 2003, 3, 1523-1539.

9. Xie, R.K.; Seip, H.M.; Liu, L.; Zhang, D.S. Characterization of Individual Airborne Particles in Taiyuan City, China. Air Qual Atmos Health 2009, 2, 123-131.

10. Stein, A.F.; Draxler, R.R.; Rolph, G.D.; Stunder, B.J.B.; Cohen, M.D.; Ngan, F. NOAA's HYSPLIT Atmospheric Transport and Dispersion Modeling System. Bulletin of the American Meteorological Society 2015, 96, 2059-2077, doi:10.1175/BAMS-D-14-00110.1.

11. Belo, L.P.; Orbecido, A.H.; Beltran, A.B.; Vallar, E.A.; Galvez, M.C.D.; Eusebio, R.C.; Ledesma, N.A.; Deocaris, C.C. Water Quality Assessment of Meycauayan River, Bulacan, Philippines. Sylvatrop 2018, 28.

12. Diwa, R.; Deocaris, C.; Orbecido, A.; Beltran, A.; Vallar, E.; Galvez, M.C.; Belo, L. Meycauayan, an Industrial City in Bulacan, Philippines: Heavy Metal Pollution in Soil and Surface Sediments and Their Relationship to Environmental Indicators. 2021, doi:10.20944/preprints202106.0439.v1.

13. Visco, E.S.; Amparo, J.S.; Mendoza, Ma.E.T.; Jimena, C.G.; Lagos, D.T.; Dumalanta, R.S. Perceived Effects of Lead Recycling to Selected Communities in Bulacan, Philippines. The Journal of Environmental Science and Management 2013, 16, 56-62.

14. Steel_Asia Meycauayan Works Available online: http://www.steelasia.com/company/plant-facilities/meycauayan-works. 
15. Mitsch, B.F.; Howle, R.H.; McClintock, S.C. Air Emissions and Control Technology for Leather Tanning and Finishing Operations; U.S. Environmental Protection Agency: USA, 1993;

16. Mwinyihija, M. Ecotoxilogical Diagnosis in the Tanning Industry; 1st ed.; Springer-Verlag New York: New York, 2010; ISBN 978-14419-6266-9.

17. Yu, D. Chromium Toxicity; Case Studies in Environmental Medicine (CSEM); Agency for Toxic Substances and Disease Registry, 2008; p. 67;.

18. Manalo, D.L.N. Environmental Performance Report and Management Plan (EPRMP) for North South Commuter Rail (NSCR) Project; Department of Transportation and Communications, 2015; Vol. 1;

19. Mandia, P.F.; Branzuela, R.L.; Castilla, R.M.; Galvez, M.C.D.; Vallar, E.A. Elemental Analysis of Air Particulates along the Meycauayan River.; De La Salle University, June 20 2017; p. 3.

20. Narido, S.J. Study of Particulate Matter at DLSU-Manila Using SEM/EDX and Gravimetric Analysis, De La Salle University, 2013.

21. Vallius, M.; Ruuskanen, J.; Pekkanen, J. Comparison of Multivariate Source Apportionment of Urban PM2.5 with Chemical Mass Closure. Boreal Environment Research 2008, 13, 347-358.

22. Chavent, M.; Guegan, H.; Kuentz, V.; Patouille, B.; Saracco, J. PCA and PMF Based Methodology for Air Pollution Sources Identification and Apportionment Wiley. Environmetrics 2009, 20, 928-942.

23. Thurston, G.D.; Ito, K.; Lall, R. A Source Apportionment of U.S. Fine Particulate Matter Air Pollution. Atmos Environ (1994) 2011, 45, 3924-3936, doi:10.1016/j.atmosenv.2011.04.070.

24. Shaltout, A.A.; Boman, J.; Al-Malawi, D.R.; Shehadeh, Z.F. Elemental Composition of PM2.5 Particles Sampled in Industrial and Residential Areas of Taif, Saudi Arabia. Aerosol and Air Quality Research 2013, 13, 1356-1364, doi:10.4209/aaqr.2012.11.0320.

25. Campos-Ramos, A.; Aragón Piña, A.; Querol, X.; Alastuey, A. Methodology for the Characterization and Identification by SemEds of Atmospheric Particles from Different Pollutions Emission. Microscopy: Science, Technology, Applications and Education 2010, 1, 329-333.

26. Genga, A.; Baglivi, F.; Siciliano, M.; Siciliano, T.; Tepore, M.; Micocci, G.; Tortorella, C.; Aiello, D. SEM-EDS Investigation on PM10 Data Collected in Central Italy: Principal Component Analysis and Hierarchical Cluster Analysis. Chem Cent J 2012, 6(Suppl 2), 22, doi:10.1186/1752-153X-6-S2-S3.

27. Mico, S.; Tsaousi, E.; Deda, A.; Pomonis, P. Characterization of Airborne Particles and Source Identification Using SEM/EDS. Eur. Chem. Bull. 2015, 4, 224-229, doi:10.17628/ECB.2015.4.224. 